\title{
Accounting
}

\section{Determinants of commercial banks’ performance: Evidence from emerging economies}

\author{
Imran Khan*, Muhammad Tahir and Nazish Umer
}

Department of Management Sciences, COMSATS Institute of Information Technology, Abbottabad, Pakistan

\begin{tabular}{l}
\hline C H R O N I C L E \\
\hline Article history: \\
Received June 5, 2015 \\
Received in revised format \\
August 162015 \\
Accepted November 22015 \\
Available online \\
November 5 2015 \\
\hline Keywords: \\
Emerging economies \\
Financial crisis \\
Panel econometrics
\end{tabular}
\begin{abstract}
A B S T R A C T
This paper examines the determinants of banks' performance in emerging economies. Sustainable growth of emerging economies depends on the financial performance of their banks'. The determinants of banks' performance are, therefore, analyzed through panel econometric techniques over the crisis period of 2008-2014 using data of the top 50 banks from the 10 sampled emerging economies. Both banks' specific and macroeconomic variables are considered in the analysis. Results reveal that macroeconomic variables like GDP and inflation are significant forces behind high Return on Assets (ROA) in emerging economies banks', however, both negatively influenced the Net Interest Margins (NIM). Among the banks' specific variables high profitability and NIM are related to high operating costs. This shows that expenses are managed properly in these economies. Further, leverage has a positive impact on both (ROA) and (NIM). While reserve requirement has negatively and significantly influence both profitability and net interest margins, which indicates the prominence of central bank's monetary policy by considering the importance of liquidity for emerging economies commercial banks in economic recovery phase.
\end{abstract}

\section{Introduction}

Financial sector stability plays a vital role in the development of an economy. Banking sector is the major sector of financial system; therefore, economic development of any country depends on good performance of banking sector. Banks in the emerging economies are not only becoming larger but also they are growing at a faster rate (Claessens \& Van Horen, 2008). Emerging markets capture more than 40 percent of world GDP and these economies continue to progress rapidly at an average of more than 7 percent per year for the past few years. Therefore, the emerging economies are considered as vital sources of world growth. This shows that world growth depends largely on growth of these economies. Development of emerging countries have also provided benefit to citizens of these countries and improved their standard of living. On the whole GDP per capita has increased to 30 percent. Emerging countries have also participation in the global market for goods and services. From 1990 there is a remarkable contribution of these emerging countries in world export of goods and services. Therefore

\footnotetext{
* Corresponding author. Tel. : +92 3145185575

E-mail address: imrankjadoon@ciit.net.pk (I. Khan) 
it is forecasted that all these conditions offer a better opportunity for growth of emerging economies banks'.

After the financial crisis, the global financial system faced new challenges. However, banks in the emerging economies have rebounded relatively quickly from the global financial crisis and despite various challenges, they face bright economic futures. The length of the recession and the post-crisis performance is one area where emerging economies did far better, partly because of structural reasons and partly because their policies worked in their favor (World Bank, Global Development Finance, 2010). Due to the loan-to-deposit ratio are low owing to net savings has saved the banks of emerging economies from the collapse of the interbank market and the need for deleveraging was also reduced (Van Horen, 2007).As a result it was possible for these banks to continue lending using growing and managed position of deposits funds. Secondly most of the emerging economies banks have high capital ratio which is almost 17 percent in Latin America and 13 percent in Asia (World Bank, Global Development Finance, 2010). This has helped to limit pressure on balance sheets of these banks.

The emerging markets banks face very different conditions in their home market as compared to advanced countries. As a large part of population in these countries is still unbanked it provides more growth opportunities for these banks in the market (Berger \& Deyoung, 2004). On the other hand advanced country banks face different situations at their domestic market because of economic weakness on the whole and continuous deleveraging among firms and households, leading to slower expected credit growth. Currently the top 25 countries for return on capital are all emerging markets (Claessens, 2008). Also emerging economies macroeconomic outlook is better than advanced economies. So as compared to advanced countries banks, emerging economies banks show a favorable position and funding conditions. These realities along with high profits bring these banks in a good position to further expand their global reach.

As large part of population is unbanked, most of the banks in emerging economies face pressure to increase lending which diminishes funds available for foreign expansion (Brealeyand Kaplanis, 1996). Also a large part of deposit funds are stuck in state banks of these economies which creates hurdles for these banks to expand further. Emerging economies banks have kept very limited provisions as compared to advanced country banks. This exerts pressure on these banks to increase their reserves for bad debts. Regulators also oppose to use their domestic funds in foreign finance because they consider it risky for their country. However few recent examples in Russia, Chile and Turkey indicate that emerging economies banks in the coming years possess the potential to grow not only in their home market but also abroad. It is difficult to reap profits in advanced countries because of sovereign debt problems, and low expected economic growth. This makes investment easier in other emerging markets as compared to advanced markets. As many emerging economies have high return on capital but it is still difficult to operate in these markets. For example return on capital in Pakistan in 2011 was 36 percent but due to political and operational risk the banking sector kept small. If the investment is made in smaller and poorer countries by emerging market banks it could provide better advantage because they have better chance of generating profits in these markets (Focarelli \& Pozzolo, 2000).

Commercial banks' performance has been the major concern of economic planners, management and investors. Performance of banks has great impact on economic performance of a country. Therefore an analysis of the emerging world may help their management, government and investors for maintaining high growth. Management would have to make new strategies for the better firms' performance. Also investors could gain guidance to manage their portfolios in a better way. Government could make decisions regarding the economic situation of the country by analyzing the firms' performance. Commercial banks' performance is of great interest in the emerging economies because of the functions they perform in the economy. They contribute to the growth of GDP, provide employment opportunities, and are source of finance for many other economic sectors. Also commercial banks provide opportunities for investors. 
This study has selected emerging economies due to their phenomenal growth and growing importance in globalized world. Since 1980 the financial sector has undergone major financial reforms due to the important changes in worldwide financial sector. However role of banks remain fundamental in accelerating economic activity in the country. A study of underlying factors for banks' performance has become important for both academic researchers and banks' management. Banks' performance is studied widely for US and European markets and to some extent for large emerging markets such as Brazil, China and other emerging economies. The main explanatory factors would be discussed here that could affect banks’ performance in emerging economies.

In this paper performance of banks' in major emerging economies are analyzed by considering the top banks' of each country on the basis of their assets size. Banks' performance is studied by observing return on assets (ROA) and net interest margins (NIM) by analyzing the impact of different firm specific and macroeconomic variables. The objective of this study is to extend the earlier work on various macroeconomic and bank specific variables by considering the performance of banking sector in major emerging economies. The primary objective of this study is to analyze determinants of performance operationally and financially at both bank specific and macroeconomic level. The differences in banks' performance would be examined to investigate those factors that became the cause of these differences. Results of such study could benefit managers of banks in emerging countries to better understand current conditions of the industry and establish their new goals properly.

The remaining portion of the paper is divided in four sections, the first would explain brief explanation of factors related to banks' performance, the second would provide model, sample, variables, and data collection sources, third describe results and fourth reports summary conclusion and findings.

\section{Literature Review}

Banking sector performance has been analyzed by many researchers in their studies of such countries that are either developed or passing through the developing phase (Saunders \& Schumacher, 2000; Molyneux \& Thornton, 1992; Berger, 1995a; Bourke, 1989). Financial stability of emerging economies is affected by their economic growth and inflation because it strikes upon credit allocation and bank intermediation costs directly (Martinez-Peria \& Mody, 2004; Brock \& Rojas-Suarez, 2000a, b). Maintenance of Bank intermediation cost and availability of credit is essential for financial stability of any country and macroeconomic variables affect them (Bourke, 1989; Saunders \& Schumacher, 2000; Martinez-Peria \& Mody, 2004). Many studies in different regions of the world show that both bank specific and macroeconomic variables affect bank performance (Demirguc-Kunt \& Huizinga, 1999; Athasanoglu et al., 2006, 2008; Doyran, 2013).

Both single and cross country studies have analyzed banking sector performance through the impact of their determinants. These determinants of banks' performance can be divided into both internal and external factors. Among internal determinants bank specific factors at firm level include credit risk, liquidity risk, managerial efficiency, cost inefficiency etc. On the other hand macroeconomic factors are including external determinants that affect economic growth, financial regulations, inflation (Bourke, 1989; Athasanoglu et al., 2008).

Banks that have higher operating expenses have higher net interest margins and profitability levels. This has been supported by the study of (Ben Naceur \& Goaied, 2008) who found a positive relationship between operating expenses and banks performance. They also found that there is a negative relationship between size and profitability. Some of the studies on return on assets (ROA) and net interest margin (NIM) have been used as the dependent variables and other macroeconomic and bank specific variables exist as independent variables (Yilmaz, 2013). For measuring banks performance net interest margin (NIM) has been considered mostly in the literature (Gerlach et al., 2003; Claeys \& Vander Vennet, 2008).Net interest margin is the major variable in the financial system. Higher interest 
margins can discourage people from depositing money because of too low returns on deposits and results in decreasing financing for borrowers thus affecting the growth of the overall economy.

The work of Barajas et al. (1999) shows that high interest margins can also help in strengthening the banking system of a country through higher capital ratio. On the other hand, Doliente (2003) has found that low spreads cannot always produce positive results in poorly regulated environments. In such systems if weak banks operate they will offer loans at lower rates to get rid of troubles.

Both the microeconomic and macroeconomic conditions of different countries have been analyzed in many studies on Latin America. During the mid-1990s in Chile, Argentina, Bolivia, Mexico, Colombia, Uruguay and Peru the high interest rate spreads and its determinants have been researched by Brock and Rojas-Suarez (2000a, b). They concluded through their analysis that interest spreads increase due to high operating expenses, and capital inadequacy. Similarly changes in level of GDP and rate of inflation also cause increase in interest rates. Banks' profitability has a positive relationship with liquidity (Bourke, 1989). There is an increase in profitability if lesser collection of funds is used in liquid investment (Eichengreen \& Gibson, 2001).

Bank size has been used mostly in literature. The size of bank is important because many operations of the bank depends upon it like risks, cost differences and products functioning which are managed according to the size. A positive relationship between banks' profitability and size exists if economies of scale are significant (Akhavein et al., 1997; Bikker \& Hu, 2002; Chirwa, 2003). It has also been analyzed by different researchers that if the size of banking firm increases, saving of cost can be gained as markets gets bigger and developed (Boyd \& Runkle, 1993; Athanasoglou et al., 2008).

Theory shows that larger banks generate larger profits but if a bank grows beyond a certain level it becomes difficult to manage financial organizations. There are mixed results regarding this relationship. (Goddard et al., 2004) find a positive relationship but there also exists some studies that show negative relationship (Kosak \& Cok 2008; Dietrich \& Wanzenried, 2011) between size and profitability.

A positive relationship exists between operational inefficiency and higher margins. The same has been concluded from the past studies that banks which have greater costs function with greater interest margins (Valverde \& Fernández, 2007). Drakos (2003) and Elian and Valentine (2005) have done their analysis on liquidity. Different bank specific factors like liquid assets, loan quality and operating expenses affect the performance of banks' (Gizycki Min, 2001). The major indicators of the bank profitability are leverage, earnings and efficiency (European Central Bank, 2012).

Inflation has a main impact on profitability of firms. The same has been analyzed by the study of (Athanasoglou et al., 2006) who found that among the macroeconomic variables inflation affects the firms' profitability strongly. Performance of financial sector is affected greatly by inflation. (Hybens \& Smith, 1999) found that if the rate of inflation increases it proves economically costly for the performance of financial sector. Also it becomes difficult for firms to allocate resources and their ability generates means of resources decreases (Boyd et al., 2001). Macroeconomic conditions are affected by inflation and growth rate or per capita income (Doyran, 2013). A significant and positive impact of growth rate or gross domestic product (GDP) has been found on firm performance by (Kosmidou, 2008). Also if the economic growth rate is high it creates opportunities for banks and facilitates them to lend at large scale and also charge higher interest rates. This has also been concluded from the study of (Doyran, 2013) who analyzed banks’ performance with the increase in growth rate.

In many emerging countries reserve requirement holds a main role as a significant instrument for policy formulation (Glocker \& Towbin, 2012). The use of reserve requirements have been analyzed by Quizpe and Rossini (2010), Mesquita and Toros (2010) and Herrera et al. (2010) in different countries like Peru, Brazil and Colombia. It can also be considered that the banks' two way position for providing 
sources of liquidity for various firm in the economy of transmission belt for monetary policy (Corrigan, 1982). The role of reserve requirements has been very important in emerging economies and in past the major research work on reserve requirement in emerging economies examined the effect of reserve requirement on bank profits and interest margins (Azevedo \& de Carvalo, 2004).

Profitability refers to a situation when the income is more than the expenses during a given period over the same length of time period for the main purpose of generating income (Banwo, 1997; Sanni, 2006). The main requirement is that income and expenses must exist at the same time period and income should result from expenses allocation. Profit earning is the main aim of a profit oriented organization. The business continues as long as there are positive expectations of increasing profitability but in a situation where it becomes impossible to create profit the business also close down. Return on assets (ROA) and net interest margins (NIM) are mostly considered as profitability indicators in literature (Ahmed, 2003). For this study we have used these two widely used indicators ROA and NIM.

\section{Data, Methodology and Variables Selection}

This study has chosen 50 large banks from 10 emerging economies. These emerging economies are chosen from the group of 25 emerging economies based on the IMF listing criteria of 2012. The determinants of banks' profitability are analyzed with the data from 50 commercial banks of respective countries between the years 2008 to 2014. The names of emerging countries are Argentine, Brazil, Chile, China, India, Pakistan, Poland, Russia, South Africa, and Turkey, while the list of respective banks is given in the appendix. The financial data was collected from secondary sources like central bank of respective countries' annual reports and annual reports of selected commercial banks. Economic Growth (GDP) and Consumer price index (CPI) data obtained from World Bank (WDI, 2013). Reserve requirement obtained from IFS (international financial statistics). Table 1 defines the variables that measure performance along with those of the internal (firm-level) and some external (micro and macro) determinants.

\section{Table 1}

Definition of Variables

\begin{tabular}{ll}
\hline Variable & Description \\
\hline ROA & Return on assets: is a measure of profitability and calculated as net income over total assets \\
NIM & Net interest margin: is calculated as net interest income over total assets \\
OPTEXP & $\begin{array}{l}\text { Operating expenses: is a measure of cost efficiency/inefficiency and calculated as total non-interest } \\
\text { expense over total assets }\end{array}$ \\
LEVR & Leverage: is a measure of risk and calculated as total liabilities over total assets \\
RR & Change in reserve requirement \\
GDP & Growth rate \\
INF & Inflation: represents the inflation rate which is measured as consumer prices annual percentage and used \\
\hline
\end{tabular}

According to standard literature the ratios that are mostly used are ROA and NIM to measure performance (Goldberg \& Rai, 1996; Angbazo, 1997). Therefore the determinants are analyzed by considering these performance indicators ROA and NIM. The tests are applied for both indicators of emerging market banks'. Profitability is measured by using the proxy ROA and it describes the efficiency of bank in generating returns from assets. ROE is a famous measure of performance but it lacks the ability to capture the risk sensitive factors of bank such as risky assets and liquidity of banks'. Therefore ROA is normally considered as a more appropriate performance indictor for banks' than ROE.

In this study, the NIM is the second measure which is used to measure performance. NIM is widely used and measures the cost of financial intermediation. It is also a suitable variable for asset and liability management which means that if a bank earns more income on the loans as compared to costs on deposits NIM of bank becomes higher (European Central Bank, 2010). The effect of NIM is examined by considering that banks 'earn income from assets with high interest and liabilities with low interest 
costs. This has been confirmed by the study of Brock and Rojas-Suarez (2000a, b) which showed that if the operating costs become higher it results in higher interest margins for banks. Also Angbazo (1997) examined that interest margins of banks' depends upon interest risk and liquidity risk which shows that risky loans increases default risk and also results in higher interest-rates on loans thus increasing NIM for banks. Table 2 reports the descriptive statistics and firm averages of performance indicators.

Table 2

Descriptive Statistics

\begin{tabular}{llllll}
\hline & Observations & Mean & Minimum & Maximum & St.Div. \\
\hline GDP & 350 & 4.22 & -7.80 & 10.50 & 3.77 \\
INF & 350 & 7.11 & -0.70 & 20.30 & 4.01 \\
RR & 350 & 11.65 & 2.50 & 20.60 & 6.56 \\
OPTEXP & 350 & 0.028 & 0.002 & 0.080 & 0.019 \\
LEVR & 350 & 0.90 & 0.80 & 0.96 & 0.03 \\
\hline
\end{tabular}

In the current study a positive relationship is expected between operating expenses and NIM. Banks which are inefficient try to reduce costs by charging high interest income on their assets and in this way transfer the expenses to customers. With the increase in interest charges loan demand decreases. Also a negative relationship is expected between operating expenses and banks' profit (ROA). If the ratio of expenses is higher it shows cost inefficiency and lower profitability. Such banks having higher costs also have higher NIM. Leverage which is the measure of total liabilities (debt) to total assets shows the bank capital. Leverage is used as a measure of risk and it can affect profitability both positively and negatively. Lower ratio of leverage shows a less risky situation for the bank which has a positive impact on profitability. Higher debt raises the cost of capital and financial distress because default risk increases. The same is supported by the study of (Athasanoglu et al., 2006) which shows that higher capital increases risk of default and gives higher losses to banks. ROA and NIM are also affected by macroeconomic conditions.

Among the macroeconomic variables, GDP and inflation are used. This variable is expected to have a positive impact on bank profitability and NIM according to the literature (Kosmidou, 2008). The other macroeconomic variable is inflation that affects both the cost and earnings of banks'. Studies regarding INF indicate both positive and negative results. Some studies reveal that there is a negative relationship between inflation and banks' performance. According to (Boyd et al., 2001) high inflation have negative effects on financial and banking system of countries. NIM increases in the presence of inflation according to (Demirguc-Kunt et al., 2004). Also some studies found positive relationship between inflation and banks’ performance (Molyneux \& Thornton, 1992). It depends upon the nature of analysis and whether inflation is anticipated or not (Perry, 1992).

\subsection{Model Estimation}

This study uses fixed effect model with panel data analysis for the period 2008-2014. Performance of emerging economies commercial banks are analyzed using panel regression analysis that considers bank-specific variables and other macroeconomic determinants. Both ROA and NIM are considered as measure of banks' profitability and performance. Internal and external components of banks' performance are analyzed by considering the models used in the literature (Demirguc-Kunt \& Huizinga, 1999; Kosmidou, 2008; Chortareas et al., 2011).

\section{Model 1 (NIM-based)}

$N I M_{\mathrm{it}}=\beta_{0}+\beta_{1} O P T E X P_{\mathrm{it}}+\beta_{2} L E V R_{\mathrm{it}}+\beta_{3} R R_{\mathrm{it}}+\beta_{4} I N F_{\mathrm{it}}+\beta_{5} G D P_{\mathrm{it}}+\epsilon_{\mathrm{it}}$ 
Model 2 (ROA-based)

$R O A_{i t}=\beta_{0}+\beta_{1} O P T E X P_{\mathrm{it}}+\beta_{2} L E V R_{\mathrm{it}}+\beta_{3} R R_{\mathrm{it}}+\beta_{4} I N F_{\mathrm{it}}+\beta_{5} G D P_{\mathrm{it}}+\epsilon_{\mathrm{it}}$

Hausman Test (1978) is formulated to assist in making a choice between the fixed effects and random effects approaches. Based on a Hausman (1978) specification test the null hypothesis is rejected in favor of alternative hypothesis. Since the test probability (p for ROA $=0.012 \&$ p for NIM $=0.0451$ ) is less than the critical value of 0.05 , we consider the fixed effects model to be more appropriate than the random effects model.

In order to analyze the determinants of banks' performance for emerging economies, the current analysis applied the model used by Demirguc-Kunt and Huizinga (1999), Barajas et al. (2000) and Bawumia et al. (2005), in which bank performance is analyzed on the basis of different bank specific and macroeconomic variables. Thus the model was analyzed by considering bank as a profit maximizing firm with bank specific and macroeconomic variables.

For analyzing the collective response of performance to different variables the fixed effect model is used. Cross sectional weighting of balanced panel is used for linear estimation after one-step weighting matrix, and each bank observations consists of cross section. Insignificant terms are not included to gain frugality.

\subsection{Results and discussion}

Empirical results reported in Table 3, indicate that there is a positive and significant coefficient on operating expenses in both ROA and NIM equations.

Table 3

Fixed Effect Model Results

\begin{tabular}{|c|c|c|c|c|}
\hline \multicolumn{5}{|c|}{ Dependent Variable Profitability (ROA) } \\
\hline Independent Variable & Coefficient & Std. Error & t-Statistic & Prob. \\
\hline $\mathrm{C}$ & 2.250189 & 0.012241 & 183.8238 & 0.0000 \\
\hline GDP & 0.005313 & 0.003336 & 1.592577 & 0.1034 \\
\hline INF & 0.017347 & 0.004610 & 3.762966 & 0.0002 \\
\hline RR & -0.011073 & 0.005281 & -2.096715 & 0.0378 \\
\hline OPTEXP & 12.83895 & 5.031020 & 2.551958 & 0.0117 \\
\hline LEV & 1.645510 & 0.901333 & 1.825641 & 0.0700 \\
\hline R-squared & 0.958555 & & & \\
\hline Adjusted R-squared & 0.943120 & & & \\
\hline F-statistic & 62.10399 & & & \\
\hline Prob. (F-statistic) & 0.000000 & & & \\
\hline Durbin-Watson stat & 1.931601 & & & \\
\hline \multicolumn{5}{|c|}{ Dependent Variable Net Interest Margin (NIM) } \\
\hline Independent Variable & Coefficient & Std. Error & t-Statistic & Prob. \\
\hline $\mathrm{C}$ & 1.931601 & 0.129131 & 6.834825 & 0.0000 \\
\hline GDP & -0.151967 & 0.023488 & -6.470075 & 0.0000 \\
\hline INF & -0.029542 & 0.019159 & -1.541893 & 0.1064 \\
\hline $\mathrm{RR}$ & -0.123866 & 0.015060 & -8.225083 & 0.0000 \\
\hline OPTEXP & 26.06913 & 8.401649 & 3.102858 & 0.0025 \\
\hline LEV & 4.367365 & 1.202897 & 3.630705 & 0.0005 \\
\hline R-squared & 0.683554 & & & \\
\hline Adjusted R-squared & 0.503680 & & & \\
\hline F-statistic & 3.800177 & & & \\
\hline Prob(F-statistic) & 0.000000 & & & \\
\hline Durbin-Watson stat & 2.938417 & & & \\
\hline
\end{tabular}

A negative relationship between operating expenses and profitability is expected because most of the studies have indicated a negative relationship (Bourke, 1989; Demirguc-Kunt \& Huizinga, 1999; 
Athanasoglou et al., 2005). The positive description of this relationship has been described by the study of (Molyneux \& Thornton, 1992) which states that higher expenses may be utilized to increase productivity and results in higher profitability ultimately. Operating expense is positively related to NIM which means that a percentage increase in operating expense leads to 26.06 percentage increases in NIM. Also Yilmaz (2013) found positive relationship between operating expenses and NIM.

Leverage cast a significant positive impact on NIM. It follows that one percentage increase in leverage leads to 4.36 percentage increase in NIM. Leverage can have both positive and negative impact on performance of banks' as it is considered as a measure of risk. Leverage shows here a significant positive relationship with profitability ROA which means that leverage ratio has positive impact on performance of banks in terms of their profitability. These findings are consistent with the study of (Demirguc-Kunt et al., 2010) who found positive relation between ROA, NIM and Leverage. During crisis stronger capital position associated with better performance of larger banks.

Reserve ratio is found to have a negative significant impact on ROA. It indicates that a percentage increase in reserve requirement results in 0.011 percentage decreases in ROA. Also the relationship between reserve ratio and NIM is found to be negative and significant which means that increase in reserve requirement would decrease interest margins NIM of banks. As the reserve requirement increases the availability of loan able funds decreases with the banks which results in decreasing the capacity of banks to make loans. Ultimately NIM is also affected with this increase and it reduces the interest spreads. It shows that a percentage increase in reserve ratio leads to 0.12 percentage decrease in NIM of banks. This is contrary to the findings of (Glocker \& Towbin, 2012).

The reserve ratio (RR) is one of the regulations which make the banks obliged to keep a certain percentage of their liabilities with the central bank. It helps to promote the functions of the financial system, maintain the operations of banking system financial position and analyze the performance relating to risk based supervision. It is a measure that can be used to face the banking crisis situation as it provides some safety from Liquidity and solvency risk as higher the reserve ratio is it results in lower default risk. During the financial crisis many central banks reduced the reserve ratio to provide more liquidity to the banks.

Results regarding macroeconomic variables are mixed. First of all inflation positively and significantly affect profitability (ROA). Inflation is expected to affect positively on profitability if banks' income increases more rapidly than its costs. This is consistent with the results of (Demirguc-Kunt \& Huizinga, 1999) who found positive relationship between inflation and ROA. It also shows that management of bank may anticipate the rate of inflation and respond accordingly to the situation (Vong et al., 2008). When costs increase rapidly than income a negative sign of coefficient is expected. Thus results show that banks in these emerging countries tend to be more profitable in inflationary environment. On the other hand inflation has a negative impact on interest margins NIM of banks shows significant relation between NIM and inflation. Ameur and Mhiri (2013) found that net interest margin is negatively and significantly affected by inflation. This means that banks' do not manage their lending rates accordingly to inflation and ultimately these results in entire negative cost of inflation.

GDP is positively and significantly related with ROA. As the GDP of country rises, the earnings of commercial banks also increase relative to the increasing growth rate. Banks in the emerging economies are passing through the recovery phase. The magnitude of financial crisis was very large and it also affected the GDP growth rate of emerging economies. During the crisis period GDP fell from peak to trough. The duration of this period was slightly shorter for emerging economies as compared to the advanced economies which suffered badly from the financial crisis. On the other hand GDP growth is inversely related to NIM. This shows that a percentage increase in GDP results in 0.15 percentage decrease in NIM. Claeys and Vander Vennet (2009) find a negative relationship between GDP growth 
and interest rate margins; they reveal that increase in economic growth gives rise to greater lending and lower credit default.

Emerging countries entered the growth phase quickly as compared to advanced countries and GDP of emerging countries started to recover in 2010 but at a slower rate. This recovery is whether profitable for banking system or not depends upon the availability of credit and demand of banking sector services which are improving in these emerging countries but with slower pace. The improvements in the socio economic status leads to development of more lending in these emerging countries.

\section{Conclusion}

After the global financial crisis, various changes occurred in the banking system of emerging economies. This paper investigated the impact of banks' internal variables and macroeconomic changes on performance and profitability of banks' in emerging economies for the period 2008-2012. Empirical analysis is based on panel data techniques of 50 commercial banks from 10 different emerging economies.

The results reveal that among the internal characteristics of banks' operating expenses and leverage bring large changes in profitability and NIM of banks' in these emerging economies. High profitability and NIM are related to greater operating costs. Also the use of leverage brings significant results and shows positive impact on profitability and performance of banks'. Reserve requirement ratio as a measure of liquidity level is negative and significant in case of both ROA and NIM. The findings of these characteristics indicate that earnings of emerging economies commercial banks are improving and leverage is also increasing. The results of macroeconomic factors depict that inflation positively affects bank profitability and leads to higher costs resulting in higher income. It means that income is higher as compared to the costs. The impact of GDP growth rate on profitability is positive and significant but it has negative impact on interest margins.

The results also suggest that in order to maintain profitability and interest margins at a proper level there should be a well maintained capital structure and leverage for the banks'. Also the reserve requirement ratio should be managed in such a way that it should increase profitability and NIM of banks and provide required liquidity according to the circumstances faced by the banking system.

Overall the results reveal a positive and progressive environment for banks of emerging economies after the financial crisis period ended. It shows that these countries have the potential to progress further on the basis of their banking systems.

\section{References}

Angbazo, L. (1997). Commercial bank net interest margins, default risk, interest-rate risk, and offbalance sheet banking. Journal of Banking \& Finance, 21(1), 55-87.

Akhavein, J., Berger, A. N., \& Humphrey, D. B. (1997). The effects of megamergers on efficiency and prices: Evidence from a bank profit function. Review of Industrial Organization, 12(1), 95-139.

Azevedo, C., \& de Carvalo, F. (2004). The Incidence of Reserve Requirements in Brazil: Do Stockholders Share the Burden? (No. 319). Departamento de Economia da Universidade de Brasilia.

Altunbas, Y., Evans, L., \& Molyneux, P. (2001). Bank ownership and efficiency. Journal of Money, Credit and Banking, 926-954.

Athanasoglou, P. P., Brissimis, N.S., \& Delis, D. M. (2005). Bank-specific, industry-specific and Macroeconomic determinants of bank Profitability. Bank of Greece. Working Paper, 2002.

Athasanoglu, P.P., Delis, M.D., \& Staikouras, C.K. (2006), Determinants of bank profitability in the South Eastern European region. Working Paper No. 47, Bank of Greece, Economic Research Department, September 
Athasanoglu, P.P., Brissimis, S.N., \& Delis, M.D. (2008). Bank-Specific, industry-specific and macroeconomic determinants of bank profitability. Journal of International Financial Markets, Institutions and Money, 18(2), 121-136

Aburime, T.U.i (2008). Determinants Bank Profitability: Macroeconomic Evidence from Nigeria. DeakinUniversity, WorkingPaper, 1-10.

Ahmad, H. (2003). Trend in the Profitability of Banks in Nigeria Before and After Interest Rates Deregulation: A Comparative Analysis. NDIC Quarterly, 13(9), 55-84.

Brealey, R., \& Kaplanis, E. (1996). The Determination of Foreign Banking Location. Journal of International Money and Finance, 15(4), 577-97.

Bourke, P. (1989). Concentration and other determinants of bank profitability in Europe, North America, and Australia. Journal of Banking and Finance, 13(1), 65-79.

Barajas, A., Steiner, R., \& Salazar, N. (1999). Interest spreads in banking in Colombia, 1974-96. IMF Staff Papers, 196-224.

Banwo, S. (1997). The Funds flow Statement: Towards Enhanced Utility, 1997 ICAN News. July/September, 23-29.

Berger, A. N., Buch, C. M., DeLong, G., \& DeYoung, R. (2004). Exporting financial institutions management via foreign direct investment mergers and acquisitions. Journal of International money and Finance, 23(3), 333-366.

Berger, A. (1995a). The profit-structure relationship in banking: tests of market power and efficient structure hypotheses. Journal of Money, Credit and Banking, 27(2), 404-431.

Berger, A. (1995b). The relationship between capital and earnings in banking. Journal of Money, Credit and Banking, 27(2), 432-456

Boyd, J. H., \& Runkle, D. E. (1993). Size and performance of banking firms: Testing the predictions of theory. Journal of monetary economics, 31(1), 47-67.

Brock, P.L., \& Rojas-Suarez, L. (2000a). Interest rate spreads in Latin America: facts, theories, policy recommendations. in Brock, P. and Rojas-Suarez, L. (Eds), Why So High? Understanding Interest Rate Spreads in Latin America, Inter-American Development Bank, Washington, DC.

Brock, P.L., \& Rojas-Suarez, L. (2000b). Understanding the behavior of bank spreads in Latin America. Journal of Development Economics, 63(1), 113-134.

Boyd, J., Levine, R., \& Smith, B.D. (2001). The impact of inflation on financial sector performance. Journal of Monetary Economics, 47(2), 221-248.

Brock, P. L., \& Suarez, L. R. (2000). Understanding the behavior of bank spreads in Latin America. Journal of development Economics, 63(1), 113-134.

Bikker, J. \& H. Hu (2002). Cyclical patterns in profits, provisioning and lending of banks and procyclicality of the new Basel capital requirements. BNL Quarterly Review, 221, 143-175

Claessens, S., \& Van Horen, N. (2008). Location Decisions of Foreign Banks and Competitive Advantage. World Bank Policy Research Working Paper No. 4113.

Claeys, S., \& Vander Vennet, R. (2003). Determinants of bank interest margins in Central and Eastern Europe: Convergence to the West?. Economic Systems, 32(2), 197-216

Chirwa, E. W. (2003). Determinants of commercial banks' profitability in Malawi: a cointegration approach. Applied Financial Economics, 13(8), 565-571.

Chortareas, G. E., Garza-Garcia, J. G., \& Girardone, C. (2011). Banking sector performance in Latin America: market power versus efficiency. Review of Development Economics, 15(2), 307-325.

Claeys, S., \& Vander Vennet, R. (2008). Determinants of bank interest margins in Central and Eastern Europe: A comparison with the West. Economic Systems, 32(2), 197-216.

Curak, M., Poposki, K., \& Pepur, S. (2012). Profitability determinants of the Macedonian banking sector in changing environment. Procedia-Social and Behavioral Sciences, 44, 406-416.

Demirgüç-Kunt, A., \& Detragiache, E. (1997). The determinants of banking crises-evidence from developing and developed countries (Vol. 106). World Bank Publications.

Demirguc-Kunt, A., \& Huizinga, H. (1999). Determinants of commercial bank interest margins and profitability: some international evidence. World Bank Economic Review, 13(2), 379-408. 
Drakos, K. (2003). Assessing the success of reform in transition banking 10 years later: an interest margin analysis. Journal of Policy Modeling, 25, 309-317

Doyran, A. (2013). Net Interest Margin and Firm Performance in developing countries, Evidence from Argentine Commercial Banks. Management Research Review, 36(7), 720-742

Eichengreen, B., \& Gibson, H.D. (2001). Greek banking at the dawn of the new millennium. CEPR Discussion Paper.

European Central Bank (2012). Financial Stability Review. What is Financial Stability?

Elian, M., \& Valentine, T. (2005). Determinants of Australian Bank Interest Rate Margins. Center for Applied Finance Working Paper Series May 2005

Focarelli, D., \& Pozzolo, A.F. (2000). The Determinants of Cross-Border Bank Shareholdings: An Analysis with Bank-Level Data from OECD Countries. 2000 Conference Proceedings. Federal Reserve Bank of Chicago International Banking Conference.199-232

Gizycki, M. (2001). The effect of macroeconomic conditions on banks risk and profitability. Research Discussion Paper, System Stability Department Reserve Bank of Australia.

Gerlach, S., \& Peng, W. (2003). Bank lending and property prices in Hong Kong. HKIMR Working Paper.

Gelos, R. (2006). Banking Spreads in Latin America. IMF Working Paper, 06/44, International Monetary Fund.

Goddard, J., Molyneux, P. \& J. Wilson (2004). Dynamics of growth and profitability in banking. Journal of Money, Credit and Banking, 36, 1069-1090

Goddard, J., Molyneux, P., Wilson, J. and Tavakoli, M. (2007). European banking: an overview. Journal of Banking and Finance, 31(7), 1911-1935.

Goddard, J., Molyneux, P., \& Wilson, J. (2004). The profitability of European banks: A cross-sectional and dynamic panel analysis. The Manchester School, 72(3), 363-381.

Glocker, C., \& Towbin, P. (2012). Reserve Requirements for Price and Financial Stability-When are they effective?. International Journal of Central Banking, International Journal of Central Banking, 8(1), 65-114.

Herrera, H. V., Betancourt, Y. R., Varela, C., \& Rodríguez, N. (2010). Effects of reserve requirements in an inflation targeting regime: the case of Colombia.Bank of Israel Rony Hizkiyahu, 133.

Huybens, E., \& Smith, B. D. (1999). Inflation, financial markets and long-run real activity. Journal of Monetary Economics, 43(2), 283-315.

Kosmidou, K. (2008). The determinants of banks' profits in Greece during the period of EU financial integration. Managerial Finance, 34(3), 146-159.

Kunt D., A., \& Huizinga H. (2000). Financial structure and bank profitability. World Bank Mimeo.

Molyneux, P., \& Thornton, J. (1992). Determinants of European bank profitability: a note. Journal of Banking and Finance, 16(6), 1173-1178.

Martinez-Peria, M.S., \& Mody, A. (2004). How foreign participation and market concentration impact bank spreads: evidence from Latin America. Journal of Money, Credit and Banking, 36(3), 511-537

Mesquita, M., \& Torós. M. (2010). Brazil and the 2008 panic. In BIS (ed), The International Banking Crisis and Domestic Financial Intermediation in Emerging Economies, BIS Papers 54

Quizpe, Z., \& Rossini, R. (2010). Monetary policy during the global financial crisis of 2007-2009: The case of Peru. BIS Papers, No. 54. pp. 299-316

Saunders, A., \& Schumacher, L. (2000). The determinants of bank interest margins: an international study. Journal of International Money and Finance, 19(6), 813-832

Sologoub D. (2006). The determinants of bank interest margins and profitability case of Ukraine bank of Finland. BOFIT Workshop on transition economics, Helsinki, April 7-8, Institute for Economies in Transition.

Sanni, M.R. (2006). Consolidated Accounts Made Simple. Ilaro, Ogun State, Nigeria, IPS Educational Press, 178-180.

Valverde, S. C., \& Fernández, F. R. (2007). The determinants of bank margins in European banking. Journal of Banking \& Finance, 31(7), 2043-2063.

World Bank (2011). World Bank Development Indicators \& Global Development Finance, 
Ugur, A. and Erkus, H. (2010). Determinants of the Net Interest Margins of Banks in Turkey. Journal of Economic and Social Research, 12(2), 101-118

Yilmaz-Altiok, A. (2013). Profitability of Banking System: Evidence from Emerging Markets. WEI International Academic Conference Proceedings, Antalya, Turkey, January 14-16.

\section{Appendix}

\begin{tabular}{|c|c|}
\hline Argentine & $\begin{array}{l}\text { Banco Patagonia, } \\
\text { Banco Galicia, } \\
\text { Banco Macro, } \\
\text { Banco Hipotecario, } \\
\text { Banco Credicoop } \\
\end{array}$ \\
\hline Brazil & $\begin{array}{l}\text { Banco do Brasil, } \\
\text { Itau Unibanco Holding, } \\
\text { Banco Bradesco, } \\
\text { Brazilian Development Bank, } \\
\text { BancoVotorantim } \\
\end{array}$ \\
\hline China & $\begin{array}{l}\text { ICBC, } \\
\text { China Construction Bank Corporation, } \\
\text { Bank of China, } \\
\text { Agricultural Bank of China, } \\
\text { China Citic Bank }\end{array}$ \\
\hline Chile & $\begin{array}{l}\text { Banco Santander, } \\
\text { Banco del Estado de Chile, } \\
\text { Corp Banca, } \\
\text { Banco de credito e Inversiones (BCI), } \\
\text { Banco Security }\end{array}$ \\
\hline India & $\begin{array}{l}\text { State bank of india, } \\
\text { PNB, } \\
\text { Bank of Baroda, } \\
\text { IDBI Bank, } \\
\text { UCO Bank }\end{array}$ \\
\hline Pakistan & $\begin{array}{l}\text { National Bank of Pakistan, } \\
\text { Habib Bank Limited, } \\
\text { United Bank Limited, } \\
\text { MCB Bank Limited, } \\
\text { Allied Bank Limited }\end{array}$ \\
\hline Poland & $\begin{array}{l}\text { PKO Bank Polski } \\
\text { Narodowy Bank Polski, } \\
\text { Bank Pekao, } \\
\text { Bank Zachodni WBK, } \\
\text { Citi Handlowy Bank } \\
\end{array}$ \\
\hline Russia & $\begin{array}{l}\text { Sberbank, } \\
\text { VTB Bank, } \\
\text { Gazprombank, } \\
\text { Alfa Bank, } \\
\text { Rosbank }\end{array}$ \\
\hline South Africa & $\begin{array}{l}\text { Standard Bank Group (Stanbank), } \\
\text { Absa Bank, } \\
\text { Bidvest Bank, } \\
\text { NED Bank, } \\
\text { African Developmant Bank } \\
\end{array}$ \\
\hline Turkey & $\begin{array}{l}\text { Ziraat Bank } \\
\text { Garanti Bank } \\
\text { Turkiye is banksi, } \\
\text { AkBank } \\
\text { Halk Bank }\end{array}$ \\
\hline
\end{tabular}

